\title{
Decision Support System to Improve the Effectiveness of Chemical Control Against Cutworms in Sugar Beet
}

\author{
Magdalena Jakubowska ${ }^{1}$ (D) Jan Bocianowski ${ }^{2}$ (D) Kamila Nowosad $^{3}$ (D) \\ Jolanta Kowalska ${ }^{4}$ (1)
}

Received: 21 October 2019/Accepted: 3 March 2020/Published online: 21 April 2020

(C) The Author(s) 2020

\begin{abstract}
The aim of this research was to create an advisory system for commodity services and sugar beet growers to support their decisions about the use of chemical control against the cutworms. Consequently, two forecasting models for determining the chemical control time were compared: one based on a signaling method and the other based on average of [effective] temperatures necessary for caterpillars to achieve the desired $L_{2}$ stage. The date of first flights and the total number of pests on plantations were determined. The usefulness of monitoring cutworm catches was also compared with systematic observations of sugar beet fields at the moment when the mass flight of cutworm moths was identified. The beginning of oviposition, hatching of the first caterpillars and the caterpillars' growth to $10-12 \mathrm{~mm}$ was observed, and optimal date of chemical treatment against cutworms was forecasted. During the study, the time for insecticidal treatments against cutworms was determined by the signaling method between the 29th and the 41st day following the onset of the cutworm moths' mass flight. The time of treatments was determined phenologically by obtaining the sum of heat which ranged
\end{abstract}

Magdalena Jakubowska

m.jakubowska@iorpib.poznan.pl

1 Department of Monitoring and Signalling of Agrophages, Institute of Plant Protection - National Research Institute, Poznan, Poland

2 Department of Mathematical and Statistical Methods, Poznan University of Life Sciences, Poznan, Poland

3 Department of Genetics, Plant Breeding and Seed Production, Wrocław University of Environmental and Life Sciences, Wrocław, Poland

4 Department of Biological Methods and Ecological Agricultural, Institute of Plant Protection - National Research Institute, Poznan, Poland from 300.7 to $696.4{ }^{\circ} \mathrm{C}$ with an average of $523.17{ }^{\circ} \mathrm{C}$ and the sum of effective temperatures which ranged from 120.2 to $260.5^{\circ} \mathrm{C}$ with an average of $180.1^{\circ} \mathrm{C}$.

Keywords Cutworms · Monitoring ·

Integrated pest management .

Sums of effective temperatures - Decision support systems

\section{Introduction}

Sugar is produced in over 100 countries worldwide. In most years, over $70 \%$ of world sugar production is consumed domestically which allowed the development of a large export market. However, a significant share of this trade takes place under bilateral long-term agreements or on preferential terms. The main producers of sugar beet in the European Union are France, Germany, Poland, UK and Czech Republic (Rezbova et al. 2014). In 2018, sugar beet yields were lower in nearly all countries of the EU-28 than 1 year previously. The dry summer of 2018 had a relatively large impact on arable crop yields in the Netherlands. In nearly all $28 \mathrm{EU}$ countries, sugar beet yields per hectare were down in 2018. The average yield across the EU amounted to 69.1 thousand $\mathrm{kg}$ per hectare. Spain was the EU country with the highest yield. On average, almost 87 tonnes of sugar beets were harvested per hectare there last year. With 76.4 tonnes per hectare, the Netherlands performed better than most countries in Europe, although the yield was $18 \%$ down relative to 2017 . In 2018 , the total sugar beet harvest in the EU amounted to nearly 120 billion $\mathrm{kg}$, over 23 billion $\mathrm{kg}$. The largest producer in Europe is France with 39.6 billion $\mathrm{kg}$. The Netherlands ranks fifth with a production of 6.5 billion $\mathrm{kg}$; Spanish arable farmers harvested 3 billion kg of sugar beets. Polish and German 
arable farmers achieved the lowest results compared to other European countries: 50.7 and 63.3 thousand $\mathrm{kg}$ per hectare, respectively. In 2018, sugar beets were cultivated on 1.73 million hectares of land in the EU-28. With an area of 490 thousand hectares, France also had the largest cultivation area for sugar beets. Last year, France contributed $28 \%$ of the total EU crop production area. The secondlargest producer was Germany with 414 thousand hectares. Both countries occupied more than half of the sugar beet production area in the EU, while the Netherlands contributed 5\% (Eurostat 2018).

Sugar beet is attacked by many pests which may cause direct injury or may introduce virus diseases to the plant, causing severe economic loss. In most parts of the world virus diseases and nematodes appear to be the principal problem, and generally speaking, the same pests and diseases occur wherever sugar beet is grown, although the predominant ones of Europe and neighboring countries differ from those in America. Cutworms, or surface caterpillars, are the larvae of various noctuid moths (e.g., Agrotis spp.), Euxoa spp. and Xestia c - nigrum (L.) in central and northern Europe and the USA, Peridroma saucia (Hübner), Crymodes devastator (Brace) and Feltia ducens (Walker) in the USA; several species are known to damage sugar beet, usually feeding on stem bases or crowns. Larvae of many other moths (e.g., Hydraecia micacea, Loxastega sticticalis (L.), Scrobipalpa ocellatella Boyd, Spodoptera spp. and Pseudaletia unipunctata (Haworth) can also cause damage to foliage or crowns of beet plants very brief accounts are given of some of the most important species (Camprag 1973; Cooke and Scott 1995; Draycott 2006; Perveen et al. 2018). Scrobipalpa ocellatella is shown to be growing problem in sugar beet production in neighboring countries (Serbia) as well as in some years in Croatia and Hungary (Camprag 1973).

Does it seem necessary to monitor sugar factories? In this article, the authors will try to answer the question by referring to their research on sugar beets.

Widespread use of chemical pesticides has made it easier to control pests, and thus to improve the quality of the crop. However, excessive, and not always justified, use of chemicals causes numerous adverse environmental changes, including the most important ones: pressure on the environment that results in limiting the biodiversity and increasingly frequent resistance of pests to chemicals that are meant to control them. New or improved solutions would make it possible to develop pest control methods at an appropriate level, while maintaining production profitability and limiting adverse effects of pesticides. As a result of these recommendations, it is currently obligatory in Poland to use plant protection products in accordance with integrated plant protection (IPP) principles. Integrated plant protection (IPP) involves proper monitoring of the occurrence and population size of pests. In order to be the most efficient, it must be conducted on each crop and in all locations. Monitoring of harmful organisms is carried out for purposes of signaling crop protection treatments (Olszak 1999; Walczak 1999; Dąbrowski 2007). Signaling of threats to crops from pests for agricultural plant protection has been limited to only a few studies and phytophagous species (Walczak et al. 2010; Jakubowska et al. 2012). When determining the optimal time for controlling agrophages, appropriate monitoring of them must be carried out (Walczak 1999). Such monitoring involves systematic observation of pests in order to determine the severity of the disease or its stage of development as well as the population size of the pests or the percentage of affected plants. When the threshold of economic harmfulness is exceeded, a decision must be made concerning pesticide treatment (Matyjaszczyk et al. 2010; Walczak et al. 2010). Therefore, it is very important to develop, modernize and improve methods of monitoring crop pests. This information needs to be published as instructions, methodologies and guides (Walczak 2010). The occurrence of pests and their stages of development can be observed on specific sugar beet fields at different times, not only across the country but also across a province, county or locality. Monitoring small areas and even specific plantations for harmful organisms for short-term forecasting is often underestimated by manufacturers or consultants, but it is of great importance in the integrated plant protection system. A study on soil pests is a good example in support of this hypothesis. Research on the assessment of the practical application of methods and techniques used in monitoring cutworms has resulted from numerous reports on the growing population size of these pests on plantations in recent years by manufacturers, farmers as well as plant and seed protection inspectors (Jakubowska and Walczak 2007, 2008, 2009). IPM methods to control soil pests, especially the cutworm, are being researched. Determination of the optimum treatment date by systematic inspection of the fields is an important element of restricting the damage caused by cutworms on the crops with a concurrent elimination of excessive and unnecessary use of plant protection products (Garnis and Dąbrowski 2008).

The cultivation of sugar beet in Poland is of great economic importance, resulting from sugar production for domestic needs and exports. This plant leaves a very good position for follow-up plants. This is mainly due to the use of organic fertilization usually used for root crops. The decline in livestock after 1989 caused that manure production decreased and the use of catch crops, straw and sugar beet leaves as organic mass. The use of beet leaves in this way changed in the twenty-first century-they are more often used for green manure than for fodder (silage). The introduction of a sugar beet by-product to the soil 
allows limiting the use of mineral fertilizers (Wacławowicz 2013). The economic significance of sugar beet is evidenced by the area of its cultivation and root crop. The area of sugar beet cultivation in Poland in 2018 was 240 thous. ha., and the yield of sugar beet roots in 2019 was about 60.0 thousand $\mathrm{kg}$ per hectare in Poland. Root harvest reached 14.6 million tons. The average technological sugar yield was about 9 tons per ha (GUS 2019).

In Poland, many species of cutworms affect sugar beets every year, including numerous Agrotis segetum Den. et Schiff. and A. exclamationis L. (Jakubowska and Walczak 2009). These species belong to the family of owlet moths (Noctuidae), popularly known as cutworms. Owlet moths are soil pests causing considerable damage to many crops, including plantations of root crops, vegetables, cereals and ornamental plants in nurseries (Małachowska 1987). The both species produce one generation in Poland. However, it is possible for the Turnip moth to have an incomplete second generation. Even in years with a very warm vegetative period, only specimens of pupae and larvae of a second generation of Heart and dart moths have been found. The annual quantity and quality changes in specific seasons result from differences in the biotic cycles of the species (Jakubowska and Ławiński 2011; Jakubowska and Bocianowski 2013). Caterpillars are the harmful stage. Their control is very difficult due to their hidden mode of life. Successful reduction in their harmfulness depends largely on the accurate determination of the best time of chemical control. For this reason, the aim of this research was to determine the relationship between the rate of development and the air temperature and humidity in order to determine the optimum time for pest control. Cutworms are harmful primarily due to their large population size, which is heavily influenced by weather conditions and the extended time of incubation and development of voracious caterpillars. Cold winters, warm and dry springs and summers, and then dry autumns are particularly favorable for cutworms (Walczak and Jakubowska 2001; Bereś 2011).

This research was carried out with the counseling Department of the Pfeifer \& Langen Polska sugar mills. Its aim was to evaluate the use of monitoring results of the Turnip moth and the Heart and dart moth for short-term forecasting according to integrated plant protection principles.

\section{Materials and Methods}

The study was conducted from 2009 to 2015 by the Institute of Plant Protection-National Research Institute (IORPIB) (Department of Forecasting Methods for Pests and Plant Protection Economics) and Pfeifer \& Langen Polska
S.A., on 13 selected sugar beet plantations in Wielkopolska and Lower Silesia. The mean size of the plantations on which the monitoring of cutworm was conducted ranged from three to five hectares. Altogether, throughout the entire study period (2009-2015), the Turnip moth (A. segetum) and Heart and dart moth (A. exclamationis) were monitored in 28 localities (see Table 1). One light trap was mounted in each monitored location. Observations on catches of moths of the pest were carried out 1-2 times a week, from the end of April to the end July. The sugar beets were at growth stage BBCH 12-30. Adult cutworm moths were caught using light traps - one light trap on each sugar beet plantation (Jakubowska 2009; Jakubowska and Ławiński 2011; Jakubowska et al. 2012; Jakubowska and Bocianowski 2013a, b). The light traps had a glow tube (250 W mercury lamp Mix) supplied from an AC source. Moths were caught in light traps at night, from dusk until early morning (a time clock regulated the operation of the light traps from 9:00 pm to 6:00 am the next morning). Moths removed from the light traps were systematically segregated and marked. Then they were identified and separated according to species. Quantitative analysis was performed. Analysis of the studied moth family was done, and a quality-quantitative structure of Noctuidae "communities" was determined. These structures were compared in the different types of agricultural landscapes (Fibiger and Hacker 1991).

In the years of research (2009-2015), sugar beet sowing fell on average in mid-April. Depending on meteorological conditions, the earliest beets hay April 8 (2010), and the latest April 18 (2013). The cast was from 85,000 up to 95 thousand per hectare, with an average sowing standard of 1.25 seed units per hectare of seed obtained in the case of sowing density every $18 \mathrm{~cm}$ and row distribution $45 \mathrm{~cm}$.

Throughout the moth catching period, from May to late September, the temperature and relative humidity of the air were recorded using data from field meteorological stations owned by the Experimental Field Station of the Institute of Plant Protection-National Research Institute (Winna Góra), the Research Centre for Cultivar Testing (COBORU) (Turew, Szelejewo, Leszno, Kościelna Wieś) and GlaxoSmithKline (GSK-Poznań).

From these observations, the date of the moths' first flights and the total number of pests on plantations were determined. The usefulness of monitoring cutworm catches was also compared with the systematic control observations of the plantation from the moment of the moths' mass flight.

Observations were made of the beginning of egg laying, the hatching of the first caterpillars and the caterpillars' growth to $10-12 \mathrm{~mm}$ to determine the optimal date of chemical treatment. The date of pest control treatment was based on the moths' flight (Zacha 1966) and 
Table 1 The mean values and standard deviations (SD) of the number of occurrence of Turnip moth and Heart and Dart moth in particular localities in 2009-2015

\begin{tabular}{|c|c|c|c|c|}
\hline \multirow[t]{2}{*}{ Locality } & \multicolumn{2}{|c|}{ Agrotis segetum } & \multicolumn{2}{|c|}{ A. exclamationis } \\
\hline & Mean & SD & Mean & SD \\
\hline Borszyn Mały & 4.333 & 2.082 & 8 & 6.928 \\
\hline Boryszyn & 10.75 & 6.397 & 14.5 & 3.109 \\
\hline Choryń & 2 & 2.828 & 4 & 1.414 \\
\hline Czachorowo & 3.833 & 2.639 & 5.667 & 2.16 \\
\hline Dębnica & 4.25 & 3.948 & 9.25 & 10.782 \\
\hline Drożdżyce & 4.714 & 3.592 & 7.429 & 9.964 \\
\hline Gola & 7 & 0 & 9 & 0 \\
\hline Góreczki & 5 & 0 & 8 & 0 \\
\hline Januszewo & 13 & 11.314 & 9.5 & 4.95 \\
\hline Józefów & 1.5 & 0.707 & 2 & 1.414 \\
\hline Kawcze & 6 & 0 & 2 & 0 \\
\hline Kopaszewo & 0 & 0 & 0 & 0 \\
\hline Nacław & 0 & 0 & 5 & 0 \\
\hline Napoleonowo & 3 & 0 & 6 & 0 \\
\hline Osiek & 6.25 & 3.775 & 7.25 & 5.058 \\
\hline Poznań & 4.143 & 1.864 & 13.286 & 8.845 \\
\hline Rogaczewo & 0.667 & 0.577 & 2 & 1 \\
\hline Rozalin & 10.8 & 6.87 & 12.4 & 7.021 \\
\hline Russów & 14.571 & 12.191 & 9.286 & 7.041 \\
\hline Sienno & 3 & 1.414 & 3.5 & 0.707 \\
\hline Skiereszewo & 5 & 0 & 6 & 0 \\
\hline Słone & 6 & 4.243 & 9 & 1.414 \\
\hline Staniew & 0 & 0 & 5.5 & 3.536 \\
\hline Winna Góra & 11.714 & 9.928 & 6.571 & 4.928 \\
\hline Wronów & 8 & 0 & 14 & 0 \\
\hline Wrotków & 3 & 0 & 3 & 0 \\
\hline Żołędnica & 1.833 & 1.941 & 2.667 & 1.751 \\
\hline Żukowice & 8.4 & 6.877 & 7.8 & 5.848 \\
\hline $\mathrm{LSD}_{0.05}$ & 13.384 & & 13.622 & \\
\hline
\end{tabular}

simultaneously on the sum of the heat and the sum of effective temperatures, which have a highly significant impact on the length of cutworm development until the desired developmental stage $-L_{2}$ (Jakubowska 2009). For short-term forecasting in the 4-year period of study under controlled and field conditions, the sum of heat was $501.1^{\circ} \mathrm{C}$ and the sum of effective temperatures was $230.0^{\circ} \mathrm{C}$ for the examined period of the cutworm development (Jakubowska 2009). The results of these studies were used to establish the optimal date of chemical control against cutworms by phenological criterion. It uses the calculated sum of the heat and the sum of effective temperatures of the harmful stages. The date of the treatment was determined phenologically by adding the average day temperatures (a minimum of 30 days) from the day following the initial moth mass flight (for each of the localities analyzed). Observed sugar beet plants were in the BBCH phase 31-35.

The monitoring results, i.e., population sizes of the Turnip moth and the Heart and dart moth, were analyzed statistically. Firstly, the normality of the traits was tested using Shapiro-Wilk's normality test (Shapiro and Wilk 1965). Two-way analysis of variance (ANOVA) was performed to verify hypothesis that years and months as well as years $\times$ months interaction do not affect the population size of the Turnip moth and the Heart and dart moth. Oneway analysis of variance (one-way ANOVA) was used to verify a hypothesis about the lack of effect of location on the population size of the Turnip moth and the Heart and dart moth. The significance of differences in the occurrence 
of the Turnip moth and the Heart and dart moth in the provinces of Lower Silesia and Wielkopolska was tested by the Student's $t$ test. A simple linear regression model was used to analyze the impact of the sum of the heat and the sum of effective temperatures on the population size of the Turnip moth and the Heart and dart moth. The relationship between the population size of $A$. segetum and A. exclamationis moths was evaluated using the Pearson productmoment correlation coefficient (Kozak et al. 2010). All calculations for statistical analyses were performed using the GenStat 17 statistical package.

\section{Results}

In 2013 the first Turnip moths were caught at the end of the second half of May, i.e., on 19 May in Słone, then on 23 May in Winna Góra, on 24 May in Poznań and on 30 May in Boryszyn Mały. The last flight of the Turnip moth was observed in Dębnica on 19 June (Table 2).

The other species-the Heart and dart moth-was caught the earliest, on 23 and 24 May in Winna Góra and Poznań. Throughout the growing season, when the moths were caught, the catches of adult insects of both species were most numerous in Winna Góra, Rozalin, Poznań and Drożdżyce. Mass oviposition was observed in late May and early June and lasted until the end of June. The initial $L_{1}$ stage of caterpillars was observed on plantations in mid-
June. At the end of the month, due to meteorological conditions that were favorable for pest development, different developmental stages of the cutworm caterpillars from $L_{2}$ to $L_{3}$ were reported on the monitored plantations. The average forecast date for chemical control of the cutworm in 2013 for the monitored localities fell on the 30th day (between 19 and 41 days).

Monitoring of the plantation and the use of chemical control were used to observe the beginning of egg laying by the cutworm. On average in 2014, it was observed on: June $10^{\text {th }}$, and the first hatching of young caterpillars-18 to 22 June. The mean temperature for June and July was $18.7^{\circ} \mathrm{C}$, which was not favorable for the development of caterpillars. On several monitored plantations, there were no stage $L_{2}$ caterpillars. Also, there were no harmful pests exceeding the economic threshold; therefore, it was not necessary to use chemical control on all monitored objects. Furthermore, six field observations were made after plantations had been monitored in order to verify the prediction date of chemical control against cutworm.

In 2015, the first mass flight of cutworm moths was observed mid-May (15 May) in the Słone locality and lasted until the end of May (31 May) in the Czachorowo locality. Monitoring on the plantations and the use of chemical pesticides were used to observe the beginning of egg laying, which on average in 2015 , occurred from 1 to 5 June, and the hatching of the first track was observed from 10 to 17 June. As a result of numerous vetting of monitored

Table 2 Monitoring catch moths of cutworms carried out in 2015

\begin{tabular}{|c|c|c|c|c|}
\hline \multirow{2}{*}{$\begin{array}{l}\text { Year } \\
\text { Localities }\end{array}$} & \multicolumn{4}{|l|}{2015} \\
\hline & District & $\begin{array}{l}\text { Start of mass moths' } \\
\text { flight }\end{array}$ & $\begin{array}{l}\text { Number of captured adults } A \text {. segetum Schiff. and } A \text {. } \\
\text { exclamationis L. }\end{array}$ & $\begin{array}{l}\text { Predicted date of chemical } \\
\text { treatment }\end{array}$ \\
\hline Józefów & Koźmin & 26.05 & 3 & $24.06-29.06$ \\
\hline $\begin{array}{l}\text { Boryszyn } \\
\text { Mały }\end{array}$ & Góra Śląska & 26.05 & 9 & $24.06-29.06$ \\
\hline Poznań & Poznań & 20.05 & 5 & $18.06-23.06$ \\
\hline Osiek & Kościan & 24.05 & 19 & $22.06-27.06$ \\
\hline Winna Góra & $\begin{array}{l}\text { Środa } \\
\quad \text { Wlkp. }\end{array}$ & 18.05 & 20 & $16.06-21.06$ \\
\hline Czachorowo & Gostyń & 31.05 & 10 & $29.06-04.07$ \\
\hline $\begin{array}{l}\text { Żukowice/ } \\
\text { Słone }\end{array}$ & Głogów & 15.05 & 19 & $13.06-18.06$ \\
\hline Russów & Żelazków & 20.05 & 50 & $18.06-23.06$ \\
\hline Drożdżyce & Stęszew & 27.05 & 5 & $25.06-30.06$ \\
\hline Kopaszewo & Krzywiń & -* & - & - \\
\hline Karniszewo & Mieleszyn & $-*$ & - & - \\
\hline Żołędnica & $\begin{array}{l}\text { Miejska } \\
\text { Górka }\end{array}$ & 25.05 & 5 & $23.06-28.06$ \\
\hline Sienno & Ostrowite & 25.05 & 8 & $23.06-28.06$ \\
\hline
\end{tabular}

*- lack of catches 
plantations caterpillars grew to be $10-12 \mathrm{~mm}$ long (desired for control). Control treatments, depending on weather conditions and monitored fields, were made in late June (18, 24 or 30 June). The average forecast date for the chemical control of the cutworm in 2015 for the monitored localities fell on the 31st day (29th-35th day).

All studied traits had a normal distribution. In 2013, using the signaling method, the date of the chemical treatment was set for 28 June, 8 and 15 July, i.e., between the 27th and 41st day following the initial date of the mass flight of cutworm moths. The average sum of heat that was recorded for the locality of Słone $\left(642.1{ }^{\circ} \mathrm{C}\right)$, Winna Góra $\left(608.13{ }^{\circ} \mathrm{C}\right.$ ) and Poznan $\left(619.2^{\circ} \mathrm{C}\right)$ was $623.1^{\circ} \mathrm{C}$ (the insecticide treatment was performed on 28 June). Due to technical reasons, in Boryszyn Mały $\left(700.4{ }^{\circ} \mathrm{C}\right)$, Czachorowo $\left(639.0^{\circ} \mathrm{C}\right)$, Rozalin $\left(643.8^{\circ} \mathrm{C}\right)$, Drożdżyce $\left(694.3{ }^{\circ} \mathrm{C}\right)$, Kawcze $\left(430.2{ }^{\circ} \mathrm{C}\right)$, Osiek $\left(539.7{ }^{\circ} \mathrm{C}\right)$ and Russów $\left(635.1^{\circ} \mathrm{C}\right)$ the crops were sprayed on 8 July. The average sum of heat was $611.8{ }^{\circ} \mathrm{C}$. In the other localities, the treatment was applied on 15 July when the heat sum amounted to $569.2{ }^{\circ} \mathrm{C}$ in Rogaczewo, Dębnica and Wrotków.

For comparison, in 2015, protective signaling was performed on 13 and 18 June and 24 and 29 June, i.e., between 30 and 34 days after the initial mass flight of adult moths. The sum of heat recorded for each monitored field ranged from $470.65{ }^{\circ} \mathrm{C}$ (Boryszyn Mały and Józefów) to $622.4{ }^{\circ} \mathrm{C}$ (Drożdżyce). The average sum of heat that was recorded in the monitored fields, which were subject to monitoring, performed in the $13-18$ June was $485.15^{\circ} \mathrm{C}$. In other places was performed between 24 and 29 June the sum of heat averaged $501.1^{\circ} \mathrm{C}$.

In general, there were no statistically significant differences between the localities in the incidence of the $A$. segetum $\left(F_{29 ; 59}=1.44 ; P=0.116\right)$ and the $A$. exclamationis $\left(F_{29 ; 59}=1.04 ; P=0.439\right)$. The Turnip moth occurred in far greater numbers in Lower Silesia than in Wielkopolska $(P=<0.001)$ (Table 3$)$. In contrast, the $A$. exclamationis occurred in both provinces at a similar level $(P=0.486)$.

The average air temperature for the month of June in $2014\left(16.4{ }^{\circ} \mathrm{C}\right)$, when compared to previous years, was not favorable for pest development. An analysis of the number of caterpillars made on 30 June in Winna Góra showed an average of 2.5 individuals per $1 \mathrm{sqm}$. The threshold of harmfulness was not reached (the risk threshold for caterpillars of cutworms in sugar beet is 6 per $1 \mathrm{~m}^{2}$ ). The size of the observed caterpillars corresponds to the dimensions suitable for the $L_{2}$ and $L_{3}$ stages. The average air temperature for the month of July was $19.9-20.3{ }^{\circ} \mathrm{C}$. Since these temperatures are favorable for pest development, another two dates for insecticide treatments were set in this month. In summary, it can be concluded that based on the observed caterpillars' size the chemical treatment had been determined by the signaling method with a slight delay.

The treatment date determined by means of the second method in 2015 (using the sums of heat and sums of effective temperatures) for the whole period of the cutworm development was scheduled for the following days: 18 June for the locality of Słone, and Winna Góra; 21 June for Poznań and Russów; 24 June for the locality of Osiek, Boryszyn Mały, Józefów, Żołędnica, Drożdżyce and Sienno. In the case of the first date, the sums of heat reached the following values, respectively: $538.1^{\circ} \mathrm{C}$ and $511.0^{\circ} \mathrm{C}$, next locality $541.0^{\circ} \mathrm{C}$ and $516.1^{\circ} \mathrm{C}$; then $501.1^{\circ} \mathrm{C}, 470.6{ }^{\circ} \mathrm{C}, 470.65{ }^{\circ} \mathrm{C}, 492.0^{\circ} \mathrm{C}, 540.7{ }^{\circ} \mathrm{C}$ and $492.0^{\circ} \mathrm{C}$. The sums of effective temperatures (starting with the first major flight of moths) recorded for each monitored field ranged from $143.65{ }^{\circ} \mathrm{C}$ (Boryszyn Mały and Józefów) to $182.0^{\circ} \mathrm{C}$ (Poznań). The observed caterpillars in the field had a size corresponding to the $L_{2}$ stage (Table 4).

The sum of effective temperatures in 2015 did not reach the required value determined experimentally under controlled conditions and an average of $230.0^{\circ} \mathrm{C}$ (Jakubowska 2009). Therefore, effective treatments have been made based on the determined sum of heat. An analysis of the number of cutworms made on 30 June showed an average of 1.7 individuals per $1 \mathrm{sqm}$. The threshold of harmfulness was not reached. The mean date of treatment fell on the 31 st day after the beginning of a mass flight of the moths. Just as for the needs of signaling, the cutworm caterpillars observed in the field at that time varied in size, from 0.7 to $20 \mathrm{~mm}\left(L_{1}-L_{3}\right.$ stages $)$.

In summary, it can be concluded that according to the signaling criterion the chemical treatment in 2015 was determined with a slight delay, since the sums of heat were

Table 3 The mean values and standard deviations (SD) of the number of Heart and Dart moth in depending of catches in Lower Silesia and Wielkopolska region

\begin{tabular}{llclc}
\hline Voivodeship & A. segetum & \multicolumn{2}{c}{ A. exclamationis } \\
\cline { 2 - 3 } & Mean & SD & Mean \\
\hline Dolnośląskie & 14.57 & 12.191 & 9.29 & 7.041 \\
Wielkopolskie & 5.63 & 5.647 & 7.51 & 6.383 \\
LSD $_{0.05}$ & 4.946 & & 5.033 \\
\hline
\end{tabular}


Table 4 Date of chemical treatments carried out in 2009-2015 (selected places)

\begin{tabular}{|c|c|c|c|c|c|c|c|c|c|}
\hline \multirow[t]{2}{*}{ Year } & \multirow[t]{2}{*}{ Localities } & \multirow[t]{2}{*}{ Community } & \multicolumn{3}{|c|}{ The criterion for signaling } & \multicolumn{4}{|c|}{ The phenological criteria } \\
\hline & & & D.C.T. & Sum of heat & D.S. & D.C.T. & Sum of heat & S.E.T. & D.S. \\
\hline \multirow[t]{5}{*}{2009} & Żukowice & Głogów & $20 . \mathrm{VI}$ & 543.0 & L2 & $18 . \mathrm{VI}$ & 511.4 & 123.5 & L2-L3 \\
\hline & Żołędnica & Miejska Górka & 22.VI & 522.0 & $\mathrm{~L} 2$ & 19.VI & 507.4 & 126.3 & L2-L3 \\
\hline & Dębnica & Kłecko & 22.VI & 512.4 & $\mathrm{~L} 2$ & 19.VI & 484.9 & 133.4 & L2-L3 \\
\hline & Poznań & Poznań & 22.VI & 527.5 & $\mathrm{~L} 2$ & $20 . \mathrm{VI}$ & 501.3 & 143.5 & L2-L3 \\
\hline & Russów & Żelazków & $20 . \mathrm{VI}$ & 538.1 & L2 & $18 . \mathrm{VI}$ & 507.3 & 120.2 & L2-L3 \\
\hline \multirow[t]{10}{*}{2010} & Januszewo & Kościan & 28.VI & 543.8 & L2-L3 & $28 . \mathrm{VI}$ & 543.8 & 166.6 & L2-L3 \\
\hline & Żukowice & Głogów & $28 . \mathrm{VI}$ & 470.7 & $\mathrm{~L} 2$ & $26 . \mathrm{VI}$ & 454.4 & 149.2 & L2-L3 \\
\hline & Boryszyn Mały & Góra Śląska & $28 . \mathrm{VI}$ & 444.3 & L2 & $26 . \mathrm{VI}$ & 428.0 & 144.6 & L2-L3 \\
\hline & Choryń & Kościan & 1.VII & 539.1 & L2-L3 & $28 . \mathrm{VI}$ & 502.1 & 128.6 & L2 \\
\hline & Staniew & Koźmin & 1.VII & 547.7 & L2-L3 & $28 . \mathrm{VI}$ & 502.1 & 175.1 & L2 \\
\hline & Poznań & Poznań & 1.VII & 522.8 & L2-L3 & $29 . \mathrm{VI}$ & 504.9 & 168.2 & L2 \\
\hline & Drożdżyce & Stęszew & 1.VII & 504.9 & L2 & 29.VI & 481.9 & 156.1 & L2-L3 \\
\hline & Rozalin & Słupia & 5.VII & 604.1 & L2-L3 & $30 . \mathrm{VI}$ & 503.9 & 176.9 & L2 \\
\hline & Winna Góra & Środa Wlkp. & 4.VII & 576.2 & L2-L3 & $29 . \mathrm{VI}$ & 470.4 & 165.2 & L2 \\
\hline & Russów & Żelazków & 1.VII & 615.3 & L2-L3 & $28 . \mathrm{VI}$ & 565.4 & 183.9 & L2-L3 \\
\hline \multirow[t]{13}{*}{2011} & Januszewo & Kościan & 17.VI & 488.7 & L2 & $15 . \mathrm{VI}$ & 443.9 & 182.3 & $\mathrm{~L} 2$ \\
\hline & Czachorowo & Gostyń & 11.VI & 537.0 & L2 & 9.VI & 502.0 & 197.1 & L2 \\
\hline & Żukowice & Głogów & $15 . \mathrm{VI}$ & 632.5 & L2 & $10 . \mathrm{VI}$ & 507.9 & 191.6 & $\mathrm{~L} 2$ \\
\hline & Boryszyn Mały & Góra Śląska & 17.VI & 502.4 & L2 & $15 . \mathrm{VI}$ & 462.2 & 189.7 & L2 \\
\hline & Choryń & Kościan & 4.VII & 696.4 & L3 & $20 . \mathrm{VI}$ & 519.2 & 214.0 & L2-L3 \\
\hline & Staniew (Wronów) & Koźmin & $25 . \mathrm{VI}$ & 427.3 & L2-L3 & 29.VI & 504.2 & 209.9 & L2-L3 \\
\hline & Żołędnica & Miejska Górka & 22.VI & 551.6 & L2-L3 & 17.VI & 500.0 & 205.7 & L2-L3 \\
\hline & Dębnica (Skiereszewo) & Kłecko & $30 . \mathrm{VI}$ & 561.3 & L2-L3 & 23.VI & 514.7 & 242.2 & L2-L3 \\
\hline & Poznań & Poznań & $20 . \mathrm{VI}$ & 687.3 & L3-L4 & $10 . \mathrm{VI}$ & 497.8 & 225.3 & L2-L3 \\
\hline & Drożdżyce & Stęszew & 22.VI & 652.8 & L2-L3 & 17.VI & 565.7 & 260.5 & L3 \\
\hline & Rozalin & Słupia & $15 . \mathrm{VI}$ & 593.0 & L2-L3 & $10 . \mathrm{VI}$ & 503.8 & 198.6 & L2-L3 \\
\hline & Winna Góra & Środa Wlkp. & $20 . \mathrm{VI}$ & 606.0 & L3 & $15 . \mathrm{VI}$ & 513.7 & 219.4 & L2-L3 \\
\hline & Russów & Żelazków & $20 . \mathrm{VI}$ & 574.0 & L2-L3 & $16 . \mathrm{VI}$ & 505.1 & 211.2 & L2-L3 \\
\hline \multirow[t]{10}{*}{2012} & Januszewo (Osiek) & Kościan & $15 . \mathrm{VI}$ & 482.6 & $\mathrm{~L} 2$ & $16 . \mathrm{VI}$ & 502.9 & 140.6 & $\mathrm{~L} 2$ \\
\hline & Czachorowo & Gostyń & 22.VI & 579.0 & L2-L3 & $18 . \mathrm{VI}$ & 505.0 & 167.2 & $\mathrm{~L} 2$ \\
\hline & Rogaczewo & Kościan & $25 . \mathrm{VI}$ & 431.5 & L2-L3 & 27.VI & 465.2 & 149.9 & L2-L3 \\
\hline & Staniew (Wronów) & Koźmin & $15 . \mathrm{VI}$ & 300.7 & $\mathrm{~L} 2$ & $26 . \mathrm{VI}$ & 507.1 & 182.0 & L3 \\
\hline & Dębnica (Skiereszewo) & Kłecko & $29 . \mathrm{VI}$ & 564.9 & L3 & $26 . \mathrm{VI}$ & 507.1 & 182.0 & L2-L3 \\
\hline & Poznań & Poznań & $15 . \mathrm{VI}$ & 547.6 & L3-L4 & 13.VI & 516.4 & 175.8 & L2-L3 \\
\hline & Drożdżyce & Stęszew & $22 . \mathrm{VI}$ & 556.7 & L2-L3 & 22.VI & 556.7 & 209.8 & L2-L3 \\
\hline & Rozalin & Słupia & $25 . \mathrm{VI}$ & 556.5 & L2-L3 & 22.VI & 500.4 & 164.7 & L2-L3 \\
\hline & Winna Góra & Środa Wlkp. & $22 . \mathrm{VI}$ & 502.8 & L3 & 22.VI & 502.8 & 169.1 & L2-L3 \\
\hline & Russów & Żelazków & 22.VI & 381.7 & L2 & $26 . \mathrm{VI}$ & 448.2 & 143.8 & L2-L3 \\
\hline \multirow[t]{9}{*}{2013} & Osiek & Kościan & 8.VI & 539.7 & L2-L3 & 8.VII & 540.1 & 224.0 & L2-L3 \\
\hline & Czachorowo & Gostyń & 8.VI & 639.0 & L2-L3 & $28 . \mathrm{VI}$ & 460.0 & 186.1 & L2-L3 \\
\hline & Żukowice/Słone & Głogów & $28 . \mathrm{VI}$ & 642.1 & L2-L3 & $23 . \mathrm{VI}$ & 587.1 & 198.0 & L2-L3 \\
\hline & Rogaczewo Wielkie & Krzywiń & $15 . \mathrm{VI}$ & 563.1 & L2-L3 & 8.VII & 435.2 & 189.0 & L2; L3 \\
\hline & Dębnica & Gniezno & $15 . \mathrm{VI}$ & 535.4 & L2-L3 & 8.VII & 435.0 & 189.0 & L2-L3 \\
\hline & Kawcze & Śrem & 8.VI & 430.2 & L2-L3 & $28 . \mathrm{VI}$ & 401.0 & 161.2 & L2-L3 \\
\hline & Wrotków & Krotoszyn & $15 . \mathrm{VI}$ & 609.2 & L2-L3 & 8.VII & 491.0 & 207.0 & L2; L3 \\
\hline & Poznań & Poznań & $28 . \mathrm{VI}$ & 619.2 & L2-L3 & $23 . \mathrm{VI}$ & 593.0 & 237.1 & L2-L3 \\
\hline & Rozalin & Słupia & 8.VI & 643.8 & L2-L3 & 28.VI & 460.0 & 187.1 & L2-L3 \\
\hline
\end{tabular}


Table 4 continued

\begin{tabular}{|c|c|c|c|c|c|c|c|c|c|}
\hline \multirow[t]{2}{*}{ Year } & \multirow[t]{2}{*}{ Localities } & \multirow[t]{2}{*}{ Community } & \multicolumn{3}{|c|}{ The criterion for signaling } & \multicolumn{4}{|c|}{ The phenological criteria } \\
\hline & & & D.C.T. & Sum of heat & D.S. & D.C.T. & Sum of heat & S.E.T. & D.S. \\
\hline \multirow{11}{*}{2014} & Winna Góra & Środa Wlkp. & 28.VI & 608.1 & L2-L3 & 23.VI & 521.2 & 195.0 & L2-L3 \\
\hline & Osiek & Kościan & 24.VI & 493.7 & $\mathrm{~L} 2$ & 26.VI & 525.6 & 201.6 & $\mathrm{~L} 2$ \\
\hline & Czachorowo & Gostyń & 1.VII & 516.0 & L3 & $6 . \mathrm{VII}$ & 618.0 & 225.3 & L3 \\
\hline & Żukowice/Słone & Głogów & 16.VI & 518.6 & $\mathrm{~L} 2$ & $20 . \mathrm{VI}$ & 580.2 & 209.2 & $\mathrm{~L} 2$ \\
\hline & Boryszyn Mały & Góra Śląska & 24.VI & 514.3 & $\mathrm{~L} 2$ & 26.VI & 543.1 & 182.6 & $\mathrm{~L} 2$ \\
\hline & Rogaczewo Wielkie & Krzywiń & 9.VII & 580.0 & $\mathrm{~L} 2$ & 3.VII & 456.1 & 183.6 & $\mathrm{~L} 2$ \\
\hline & Żołędnica & Miejska Górka & 19.VI & 540.9 & $\mathrm{~L} 2$ & 24.VI & 609.3 & 216.1 & $\mathrm{~L} 2$ \\
\hline & Poznań & Poznań & 16.VI & 539.8 & L2 & $20 . \mathrm{VI}$ & 601.8 & 206.6 & $\mathrm{~L} 2$ \\
\hline & Drożdżyce & Stęszew & 19.VI & 537.6 & L2-L3 & 24.VI & 606.0 & 218.9 & L2-L3 \\
\hline & Sienno & Ostrowite & 24.VI & 514.3 & $\mathrm{~L} 2$ & 24.VI & 514.3 & 175.6 & $\mathrm{~L} 2$ \\
\hline & Winna Góra & Środa Wlkp. & 13.VI & 527.9 & L2-L3 & $20 . \mathrm{VI}$ & 634.2 & 208.6 & L2-L3 \\
\hline \multirow[t]{11}{*}{2015} & Osiek & Kościan & 22.VI & 474.6 & L2/L3 & 24.VI & 501.1 & 152.3 & L2/L3 \\
\hline & Czachorowo & Gostyń & 29.VI & 485.4 & L3 & $30 . \mathrm{VI}$ & 503.9 & 166.0 & $\mathrm{~L} 2$ \\
\hline & Żukowice/Słone & Głogów & 13.VI & 455.8 & L2 & $18 . \mathrm{VI}$ & 538.1 & 156.9 & $\mathrm{~L} 2$ \\
\hline & Boryszyn Mały & Góra Śląska & 24.VI & 470.6 & $\mathrm{~L} 2$ & 24.VI & 470.6 & 143.6 & $\mathrm{~L} 2$ \\
\hline & Józefów & Koźmin & 24.VI & 470.6 & L2 & 24.VI & 470.6 & 143.6 & $\mathrm{~L} 2$ \\
\hline & Żołędnica & Miejska Górka & 24.VI & 492.0 & L2 & 24.VI & 492.0 & 154.0 & $\mathrm{~L} 2$ \\
\hline & Poznań & Poznań & $18 . \mathrm{VI}$ & 499.0 & $\mathrm{~L} 2$ & 21.VI & 541.0 & 182.0 & $\mathrm{~L} 2$ \\
\hline & Drożdżyce & Stęszew & 29.VI & 622.4 & L2/L3 & 24.VI & 540.7 & 159.5 & L2/L3 \\
\hline & Sienno & Ostrowite & $24 . \mathrm{VI}$ & 492.0 & $\mathrm{~L} 2$ & $24 . \mathrm{VI}$ & 492.0 & 154.0 & $\mathrm{~L} 2$ \\
\hline & Winna Góra & Środa Wlkp. & $18 . \mathrm{VI}$ & 511.0 & $\mathrm{~L} 2$ & $18 . \mathrm{VI}$ & 511.0 & 163.0 & $\mathrm{~L} 2$ \\
\hline & Russów & Żelazków & $18 . \mathrm{VI}$ & 474.8 & L2 & 21.VI & 516.1 & 156.7 & $\mathrm{~L} 2$ \\
\hline
\end{tabular}

D.C.T. date of chemical treatments; D.S. developmental stage; S.E.T. sum of effective temperatures $\left({ }^{\circ} \mathrm{C}\right)$

exceeded in many monitored plantations. Soil analyses showed that the cutworm caterpillars were 9 to $17 \mathrm{~mm}$ long, which corresponds to the $L_{2}-L_{3}$ stages (Table 4$)$. In addition, chemical treatments against these pests, carried out within the time limits specified on the grounds of flight control monitoring and field inspections, resulted in inhibiting pest development on sugar beet plantations. In the 2015 growing season in only two places male moth cutworms were not caught, in Kopaszewo and Karniszewo localities.

At the time of research, from 2009 to 2015, analysis of variance for the number of caught specimens of two cutworm species was carried out. The years $\times$ months interaction was not significant for all studied traits $(P>0.05)$. Based on results of the analysis of variance, it was found that the year was not a factor determining the population size of $A$. segetum $\left(F_{6 ; 82}=1.03, P=0.413\right)$. However, the year was a statistically significant factor for different population sizes of $A$. exclamationis $\left(F_{6 ; 82}=2.85\right.$, $P=0.014)$ (Tables 1 and 5). For comparison, from the period 2009 to 2015,2011 can be said to be a year that contributed to the development of cutworm caterpillars. A periodic increase in the population size of the cutworm was observed in 2008 and 2009, which was shown by very numerous flights of the A. segetum. In 2010, due to adverse weather conditions, the flight of cutworm moths was delayed. The maximum flights occurred in July and August. The years 2011 and 2012 were another period in which there was a hidden increase in the pest gradation. Flights of the examined moth species of Noctuinae on the observed plantations usually began during the last 10 days of May (in 2009, 2011 and 2013) and lasted until the first half of July. The length of the flights depended primarily on weather conditions. The start of the cutworms' oviposition under field conditions in the analyzed years was observed from late May to the first half of June. Warm and humid weather, with the exception of 2010, caused the caterpillars to start incubation from early June to the end of June. The date of insecticidal treatments was a statistically significant factor $(P<0.001)$ that determined the existence of the Turnip moth and the Heart and dart moth. Results of regression analysis indicated a statistically significant $(P<0.001)$ effect of the sum of heat $\left(x_{1}\right)$ and the sum of effective temperatures $\left(x_{2}\right)$ on the population size of the $A$. $\operatorname{segetum}\left(y_{1}=0.0003+0.0228 x_{1}-0.0307 x_{2},\right)$ and the $A$. exclamationis $\quad\left(y_{2}=-0.00255+0.0359 x_{1}-0.0521 x_{2}\right)$. 
Table 5 The mean values and standard deviations (SD) of the number of occurrence of Turnip moth and Heart and Dart moth in years 2009-2015

\begin{tabular}{|c|c|c|c|c|}
\hline \multirow[t]{2}{*}{ Year } & \multicolumn{2}{|c|}{ A. segetum } & \multicolumn{2}{|c|}{ A. exclamationis } \\
\hline & Mean & SD & Mean & SD \\
\hline 2009 & 6 & 6.621 & 11.615 & 8.94 \\
\hline 2010 & 6.385 & 5.173 & 7.846 & 4.997 \\
\hline 2011 & 6.692 & 8.528 & 7 & 4.865 \\
\hline 2012 & 9 & 5.244 & 11.231 & 8.298 \\
\hline 2013 & 5.385 & 7.654 & 4.231 & 3.492 \\
\hline 2014 & 3.077 & 2.178 & 5.538 & 4.274 \\
\hline 2015 & 8.091 & 9.492 & 5.818 & 5.095 \\
\hline $\mathrm{LSD}_{0.05}$ & 5.482 & & 4.925 & \\
\hline
\end{tabular}

These results correspond with some previous monitoring studies conducted on sugar beet plantations (Jakubowska and Ławiński 2011, 2012; Jakubowska and Bocianowski 2013a).

In addition, over a period of 7 years, of the research in different types of agricultural landscapes, over 5.5 of the thousands of specimens of the Noctuidae family were caught by light traps. They represented 95 species belonging to 10 subfamilies. Most species belonged to two subfamilies: Hadeninae (39 species) and Noctuinae (21 species), and they made up about $90 \%$ of the total number of caught moths. A large number of populous species of moths typical for this kind of a landscape was detected in the material. In the phenological groups of one-generation species, the majority were spring and summer species that are active in the imago stage in June with moth flights taking place in July and August. They included species from such genera as Orthosia spp., Cuculia umbratica L., Apameamonoglypha Hufn., Melanchra pisi L. and the summer species Cosmia trapezina L., Mythimna conigera Schiff., Noctua pronuba L. The multi-generation species had flights which lasted uninterruptedly from May to September, and even to the first decade of October. The majority of these species (e.g., Agrotis segetum Schiff., A. exclamationis L., Xestia c-nigrum L., Mythimna pallens L., Mamestrabrassicae L., Lacanobia oleracea L.) are wellknown pests of very economically significant crop plants. The two migrating species which were also observed: Agrotis ipsilon Hufn. and Autographa gamma L., occur but probably do not winter in Poland.

\section{Discussion}

The results of the present study may have practical applications in pest management strategies. The information will be used to share the forecasting of insect attack, as a central part of integrated pest management (IPM) and integrated production (IP). In recent years, great importance has been put on integrated plant protection programs that affect the use of multiple methods of pest control. A large impact can be made if many methods are applied to control agrophages by keeping populations of the pest below the economic threshold level while reducing the number of chemical treatments (Walczak et al. 2004, 2010). In Poland on sugar beet, the threshold of economic harmfulness for cutworm is 6 larvae per $1 \mathrm{~m}^{2}$ in stage $L_{1}-L_{2}$. Kay and Wheatley (1980), in the UK, found $34 \%$ of beetroots were damaged at a density of 14 larvae/ $\mathrm{m}^{2}$. In Denmark, damage levels of 3-68\% for beetroots are common if the larval period of A. segetum coincides with three to four dry, warm weeks (Esbjerg 1985).

The published literature indicates that both temperature and humidity have varying effects in different periods of pest development, i.e., different conditions are needed for the period of oviposition, hatching and the caterpillars' further development. Similar observations can be found in the paper by Tribel et al. (2004). They cultured cutworms in various temperature ranges and timed the caterpillars' development under field conditions. Based on the monitoring carried out with the use of light traps, the presence of many species of cutworms was shown in sugar beet sowings. The most populous group in the tested Noctuidae community were the species characteristic of open areas, related trophically to synanthropic and meadow plants. The second most populous group was composed of species characteristic of the forest and scrub plant community which feed on trees and bushes. The third of the most populous groups included species characteristic of environments linked directly with agrocenoses of beets, rape and cereal plant fields. The most numerous were Agrotis segetum and $A$. exclamationis. The population size of the individual species of moths from the Noctuinae subfamily could have been significantly affected by crops of other 
Fig. 1 Relationship between the population size of $A$. segetum and $A$. exclamationis moths

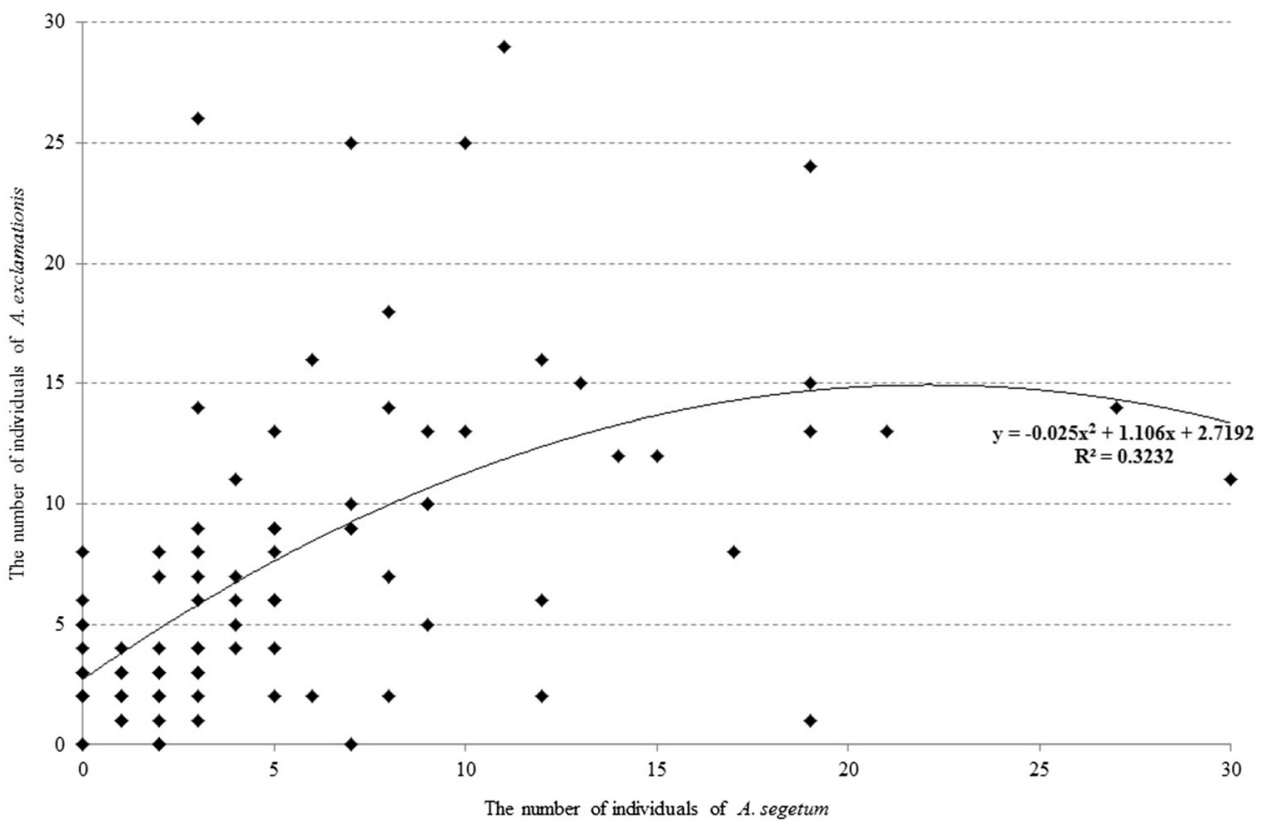

host plants surrounding the monitored sugar beet plantations. This issue has also been confirmed by other authors dealing with cutworms (Walczak and Jakubowska 2001; Garnis and Dąbrowski 2008; Bereś 2011; Jakubowska and Ławiński 2011). Moreover, in the authors' study it was found that greater numbers of the Agrotis moths were caught. There was a statistically significant correlation between the population size of the $A$. segetum and the $A$. exclamationis ( $r=0.502, P<0.001$, Fig. 1 ). In studies on the dynamics of the occurrence of cutworm moths conducted using light traps, it was found that the level of their efficiency was largely influenced by the course of the weather conditions.

Forecasting and controlling of the cutworm population growth is very difficult because there is no correlation between the number of moths caught and the number of caterpillars on plantations. Therefore, it is very important to develop methods of forecasting and evaluating the severity of the occurrence of the Noctuinae. Research on short-term forecasting based on the so-called degree-days, i.e., on adding temperatures up to a previously agreed date, in order to determine the sum of heat that is necessary for a pest to achieve the appropriate developmental stage has been carried out since the 1970s and 1980s in the USA, Denmark, Germany, the Netherlands, as well as contemporarily in Poland (Allen 1976; Pruess 1983; McMaster and Wilhelm 1997; Bonhomme 2000; Juszczak et al. 2008). In their studies, Maiorano (2012) also used two approaches to combat the European corn borer based on the accumulated values of degree-days and on the linear dependency between the daily temperature and the development of the pest. The results are promising and indicate the possibility of using them on a larger scale for the management of soil pests, such as cutworms, using the sums of heat and the sums of effective temperatures after the critical day of the moths flight has been determined by means of a light trap (Jakubowska and Bocianowski 2013b).

The results of this study confirmed that values of the sums of heat and the sums of effective temperatures are elements that support determination of the optimal time for chemical treatment against pests, the decision to carry out chemical treatment should, however, be based primarily on information on exceeding the threshold of economic harmfulness. The best effects of chemical control of the cutworms were obtained when the pest reached the full $L_{2}$ stage and at the beginning of the $L_{3}$ stage, at the same time sugar beet plants were in the $31-35 \mathrm{BBCH}$ stage. It was found a statistically significant correlation between the population sizes of the Turnip moth and the Heart and dart moth. Unfortunately, it should be stated that forecasting and controlling of the cutworm population growth is very difficult, because of no correlation between the number of moths caught and the number of caterpillars present on the plantations.

Acknowledgements Scientific publication financed by the Ministry of Science and Higher Education of the Republic of Poland.

\section{Compliance with ethical standards}

Conflict of interest None of the authors has any financial or other relationships that could lead to a conflict of interest.

Open Access This article is licensed under a Creative Commons Attribution 4.0 International License, which permits use, sharing, 
adaptation, distribution and reproduction in any medium or format, as long as you give appropriate credit to the original author(s) and the source, provide a link to the Creative Commons licence, and indicate if changes were made. The images or other third party material in this article are included in the article's Creative Commons licence, unless indicated otherwise in a credit line to the material. If material is not included in the article's Creative Commons licence and your intended use is not permitted by statutory regulation or exceeds the permitted use, you will need to obtain permission directly from the copyright holder. To view a copy of this licence, visit http://creativecommons.org/licenses/by/4.0/.

\section{References}

Allen, J.C. 1976. A modified sine wale method for calculating degree days. Environmental Entomology 5: 388-396.

Bereś, P. 2011. Occurrence and harmfulness of cutworms (Agrotinae) on maize (Zea mays L.) in south-east Poland in 2004-2010. Progress in Plant Protection 51(2): 593-598.

Bonhomme, R. 2000. Bases and limits to using 'degree-day' units. European Journal of Agronomy 13: 1-10.

Čamprag, D. 1973. Štetočine šećerne repe u Jugoslaviji, Mađarskoj, Rumuniji i Bugarskoj sa posebnim osvrtom na važnije štetne vrste. Forum, Novi Sad 363(16): 343-352.

Cooke, D.A., and J.E. Scott. 1995. The sugar beet crop technology and engineering, 456. London: Chapman \& Hall. https://doi.org/10.1007/978-94-009-0373-9.

Dąbrowski, Z. T. 2007. Forecasting methods, signaling and monitoring the occurrence of pests and thresholds of risk and economic harmful. In Integrated production of plants. The selected Issues (Editor J. Podleśny). IUNG Puławy, 33-41.

Draycott D. P. 2006. Sugar beet. Blackwell Publishing Ltd, 1-465. ISBN: 10: 1-4051-1911-x.

Esbjerg, P. 1985. Cutworms (Agrotis segetum) -forecasting and damages in 1983 and 1984. Second Danish plant protection conference, 249-260.

Eurostat. 2018. Crop production, yield, sugar beet. http://apsso. eurostat.ec.europa.eu/niu/show.do?query=BOOKMARK.

Fibiger, M., and H. Hacker. 1991. Systematic list of the Noctuidae of Europe. Esperiance 2: 1-109.

Garnis, J., and Z.T. Dąbrowski. 2008. Practical evaluation of methods and techniques used in monitoring cutworm (Agrotis segetum L.). Progress in Plant Protection 48(2): 836-840.

Główny Urząd Statystyczny. 2019. Wynikowy szacunek głównych ziemiopłodów rolnych $i$ ogrodniczych w 2019 roku. https://stat.gov.pl/obszary-tematyczne/rolnictwo-lesnictwo/ uprawy-rolne-i-ogrodnicze/wynikowy-szacunek-glownychziemioplodow-rolnych-i-ogrodniczych-w-2019-roku,5,18.html.

Jakubowska, M. 2009. Improving the forecasting of short-term chemical protection of sugar beet against Agrotis segetum (Den. et Schiff.) and Agrotis exclamationis (L.) (Lepidoptera: Noctuinae). $\mathrm{PhD}$ thesis, Institute of Plant Protection-National Research Institute. Poznań, 176.

Jakubowska, M., and J. Bocianowski. 2013a. Ocena wykorzystania wyników monitoringu rolnicy zbożówki (Agrotis segetum Den. et Schiff.) na plantacjach buraka cukrowego w latach 2009-2012. Progress in Plant Protection 53(4): 683-690.

Jakubowska, M., and J. Bocianowski. 2013b. The effectiveness of catching cutworm (Lepidoptera: Noctuidae: Noctuinae) (= Agrotinae) in pheromone traps and light traps, for short-term forecasting. Journal of Plant Protection 53(3): 215-221.

Jakubowska, M., and H. Ławiński. 2011. The usefulness of the results of monitoring cutworm (Agrotis sp.) on the plantations of sugar beet for the protection of plants. Progress in Plant Protection 51(2): 570-576.

Jakubowska, M., H. Ławiński, and A. Bandyk. 2012. Monitoring rolnic (Noctuinae) jako element integrowanej ochrony buraka cukrowego. Progress in Plant Protection 52(2): 229-234.

Jakubowska, M., and F. Walczak. 2007. Determination of optimum timing for chemical control of cutworms using light traps and pheromone traps. Progress in Plant Protection 47(1): 238-243.

Jakubowska, M., and F. Walczak. 2008. Influence of temperature and relative humidity on chosen development stages of Agrotis segetum Den. et Schiff. for requirements of short-term forecasting. Progress in Plant Protection 48(3): 859-863.

Jakubowska, M., and F. Walczak. 2009. Current problems of sugar beet plants against Turnip moth and Heart and Dart moth. Progress in Plant Protection 49(1): 116-121.

Juszczak, R., J. Leśny, and J. Olejnik. 2008. Suma temperatur efektywnych jako element prognozy agrometeorologicznej Wielkopolskiego Internetowego Serwisu Informacji Agrometeorologicznej. Acta Agrophysica 12(3): 409-426.

Kay R. H., and G. A. Wheatley. 1980. Some observations on the biology of the turnip moth (Agrotis segetum) relevant to its control with insecticides. British Crop Protection Council: Proceedings of the 1979 British Crop Protection ConferencePests and diseases (10th British Insecticide and Fungicide Conference) 19 th to 22 nd, November 1979, vol. 1,2 and 3 British Crop Protection Council Craydon, Surrey UK, 215-222.

Kozak, M., J. Bocianowski, S. Sawkojć, and A. Wnuk. 2010. Call for more graphical elements in statistical teaching and consultancy. Biometrical Letters 47(1): 57-68.

Maiorano, A. 2012. A physiologically based approach for degree-day calculation in pest phenology models: the case of the European Corn Borer (Ostrinia nubilalis Hbn.) in Northern Italy. International Journal of Biometeorology 56: 653-659.

Małachowska, D. 1987. Metody sygnalizacji terminu zwalczania rolnicy zbożówki w Polsce. Gazeta Cukrownicza 2: 41-42.

Matyjaszczyk, E., A. Tratwal, and F. Walczak. 2010. Wybrane Zagadnienia Ochrony Roślin w Rolnictwie Ekologicznym $i$ Integrowanej Ochronie Roślin. Inst. Ochr. Roślin-PIB. Poznań, 103.

McMaster, G.S., and W.W. Wilhelm. 1997. Growing degree-days: one equation, two interpretations. Agricultural and Forest Meteorology 87: 291-300.

Olszak, R.W. 1999. Monitoring jako zasada racjonalnej ochrony roślin sadowniczych. Progress in Plant Protection 39(1): 298-304.

Perveen, F. K. ed. 2018. Moths. Pests of potato, maize and sugar beet. ISBN 978-1-78984-704-8. http://dx.doi.org/10.5772/ intechopen.73423.

Pruess, K.P. 1983. Day-degree methods for pest management. Environmental Entomology 12: 613-619.

Rezbová, H., L. Smutka, J. Pulkrábek, and I. Benesová. 2014. European sugar factories, sugar companies and their alliances: Who is in control of European sugar market? Listy cukrovarnicke a reparske 130(11): 365.

Shapiro, S.S., and M.B. Wilk. 1965. An analysis of variance test for normality (complete samples). Biometrika 52: 591-611.

Tribel, S. O., W. P. Fedorenko, and O. M. Lapa. 2004. Sowki. Najposzireni v Ukraini Vidy. Kii. Kolobig, 77.

Wacławowicz, P. 2013. Siedliskowe i produkcyjne skutki polowego zagospodarowania liści buraka cukrowego. Wydawnictwo Uniwersytetu Przyrodniczego we Wrocławiu. ISBN 978-83-7717142-4.

Walczak, F. 1999. Znaczenie monitoringu agrofagów roślin uprawnych dla ochrony roślin. Progress in Plant Protection 39(1): 284-288. 
Walczak, F. 2010. Monitoring agrofagów dla potrzeb integrowanej ochrony roślin uprawnych. Fragmenta Agronomica 27(4): $147-154$

Walczak, F., and M. Jakubowska. 2001. Wzrost szkodliwości rolnic (Agrotinae) W Polsce. Progress in Plant Protection 41(2): 386-390.

Walczak, F., A. Tratwal, and T. Krasiński. 2010. Kierunki rozwoju prognozowania i sygnalizacji agrofagów w ochronie roślin rolniczych. Progress in Plant Protection 50(1): 81-86.
Walczak, F., M. Jakubowska, and H. Banaszak. 2004. Rolnicegospodarczo ważne szkodniki roślin uprawnych w Polsce. Progress in Plant Protection 44(2): 486-495.

Zacha, J.M. 1966. Prognoza a Signalizace u Ochrane Rastnin, 10. Praha: Stani.

Publisher's Note Springer Nature remains neutral with regard to jurisdictional claims in published maps and institutional affiliations. 